\title{
Pengembangan ChemOnPhone dalam Model Pembelajaran Berbasis Masalah untuk Meningkatkan Motivasi Belajar Peserta Didik
}

\author{
Joulman Cipta Alief Anugrah \\ Pendidikan Kimia, Universitas Negeri Makassar \\ Email: joulmananugrah@gmail.com \\ Sudding Sudding \\ Pendidikan Kimia, Universitas Negeri Makassar \\ Email: sudding.unm@gmail.com \\ Sulfikar Sulfikar \\ Pendidikan Kimia, Universitas Negeri Makassar \\ Email:waicinnong@gmail.com
}

(Diterima: 8-Januari-2021; direvisi: 9-Februari-2021; dipublikasikan: 26-Maret-2021)

\begin{abstract}
Abstrak: Penelitian ini bertujuan meningkatkan motivasi belajar peserta didik dalam mempelajari materi pokok kesetimbangan kimia. Maka dari itu kami mengembangkan aplikasi pembelajaran berbasis smartphone dalam model pembelajaran berbasis masalah yang bernama ChemOnPhone yang valid, praktis, dan efektif digunakan. Model pengembangan yang digunakan dalam penelitian ini mengacu pada model pengembangan Hannafin dan Peck, yang terdiri dari tahap analisis kebutuhan, tahap desain, tahap pengembangan dan implementasi. Media ChemOnPhone yang telah dikembangkan, telah melalui tahap validasi oleh validator/ahli dan telah melalui uji coba, serta mengalami revisi oleh pengembang sehingga menghasilkan media pembelajaran yang bersifat valid, praktis, dan efektif. Hasil penelitian menunjukkan bahwa media ChemOnPhone yang dikembangkan memiliki: (1) validasi ahli media 3,93 dengan kriteria sangat valid, dan (2) validasi ahli materi 3,01 dengan kriteria valid. Media ChemOnPhone dikatakan praktis dan efektif, karena pada uji kepraktisan yang berhubungan dengan: (1) keterlaksanaannya dalam model pembelajaran berbasis masalah berada pada nilai rata-rata $\mathrm{M}=1,85$ dalam kategori $(1,5 \leq \mathrm{M} \leq 2,0)$ yang artinya aspek dan kriteria yang diamati berada pada kategori terlaksana seluruhnya, (2) respon guru sangat positif dengan persentase 97,92\%, dan (3) respon peserta didik sangat positif dengan persentase $86,44 \%$. Media juga memenuhi kriteria keefektifan, dengan hasil: (1) peningkatan motivasi belajar peserta didik dari 60,88\% menjadi $84,36 \%$, (2) aktivitas belajar peserta didik dengan rata-rata 87,46 termasuk kriteria sangat aktif, dan (3) hasil belajar peserta didik memenuhi kriteria efektif ( $\geq 80 \%$ ) dimana diperoleh rata-rata persentase $88,45 \%$ yang secara keseluruhan dinyatakan memenuhi kriteria ketuntasan minimal mata pelajaran.
\end{abstract}

Kata kunci: Pengembangan; Media ChemOnPhone; Motivasi Belajar.

Abstract: This study aims to increase the learning motivation of students in studying the subject matter of chemical equilibrium. Therefore, we developed learning application based smartphone in a problem-based learning model that called ChemOnPhone which is valid, practical and effective to use. To achieve this aim, we followed the Hannafin and Peck's model development phases: analysis, design, development and implementation. The ChemOnPhone we built had been through validation processes by an educational media and a subject content experts. We then revised the app accordingly by considering these expert reviews until the app considered as valid. To evaluate the practicality and the effectiveness of 
the app, we then tried it out to Year XI Science students of SMAN 2 Sidrap. The results of media validation and trial showed that: (1) the media was very valid (marked 3.93 out of 4), (2) the content was valid (marked 3.01 out of 4). ChemOnPhone was also considered practical and effective based on (1) The implementation was graded as effective $(\mathrm{M}=1.85,1.5 \leq \mathrm{M} \leq$ 2.0 ), (2) The approval rate was $97.2 \%$ and $86.4 \%$ by teachers and students, accordingly. ChemOnPhone has met the effective criteria as (1) students learning motivation improved from $60.9 \%$ out of $84.4 \%$, (2) students learning activity was averagely $87.5 \%$, which met the active criterion, and (3) the average learning results achieved was $88.4 \%$ out of $100 \%$, which pass the effective criteria of $\geq 80 \%$. Overall, ChemOnPhone was valid, practical and effective to use in learning the chemical equilibrium subject.

Keywords: Development; ChemOnPhone Media; Learning Motivation.

\section{PENDAHULUAN}

Perkembangan teknologi informasi
dan komunikasi telah mendorong
terciptanya berbagai inovasi. Pada dunia
pendidikan, pemanfaatan perangkat
teknologi informasi dan komunikasi
seringkali hanya digunakan untuk membantu
kegiatan administrasi di sekolah saja,
padahal perangkat teknologi informasi dan
komunikasi dapat dimanfaatkan lebih jauh
untuk meningkatkan kualitas pembelajaran
di ruang kelas dengan cara mengintegrasikannya ke dalam kurikulum yang ada (Gora dan Sunanto, 2010).

Pembelajaran efektif sangat diperlukan dalam pembelajaran agar tujuan pembelajaran dapat tercapai dengan baik. Kemampuan guru dalam menyampaikan pembelajaran dan menggunakan serangkaian perangkat pembelajaran untuk menunjang proses pembelajaran harus dilakukan secara maksimal sehingga tujuan pembelajaran yang diinginkan dapat tercapai. Kemampuan yang harus dimiliki oleh guru adalah merancang perangkat pembelajaran dengan mengaitkan konteks dunia nyata peserta didik, mampu menerapkan model dan pendekatan dalam pembelajaran yang dapat menarik minat peserta didik dengan mengaitkan apa yang mereka pelajari dengan konteks dunia nyata atau bersifat kontekstual.

Pembelajaran yang dilakukan sekarang dituntut untuk menggunakan model pembelajaran yang disarankan oleh kurikulum 2013, salah satunya adalah model discovery learning. Di SMAN 11 Makassar sendiri telah menerapkan kurikulum 2013 dengan proses pembelajaran yang masih bersifat konvensional. Salah satu model yang sering diterapkan oleh guru adalah model pembelajaran discovery learning akan tetapi pengaplikasian dalam kelas masih susah untuk mengaktifkan dan mengembangkan kemampuan peserta didik, proses pembelajaran atau perangkat yang dirancang belum terlalu mengaitkan pembelajaran dengan lingkungan atau dunia nyata peserta didik sehingga peserta didik menganggap kimia tidak menarik, dan perangkat yang seharusnya menjadi pedoman bagi seorang guru dalam melakukan proses pembelajaran tidak berjalan semestinya. Terkadang peserta didik menggunakan sumber belajar dari buku paket yang disediakan oleh guru atau buku yang tersedia di perpustakaan. Penerapan proses pembelajaran yang bersifat konseptual hasilnya belum memuaskan, dari beberapa peserta didik masih ada yang belum memenuhi standar ketuntasan kelas sebesar $80 \%$ dan untuk ketuntasan materi yaitu 75 .

Keadaan ini kurang memberi harapan bagi kelangsungan suatu proses pembelajaran yang efektif dan efisien, sehingga tidak tercapai tujuan pembelajaran yang telah disusun sebelumnya. Oleh karena itu, aspek yang mendukung proses pembelajaran harus disertakan pada proses pembelajaran dikelas mulai dari RPP, bahan ajar, media, lembar kerja peserta didik (LKPD) serta alat evaluasi atau yang sering dikenal dengan tes hasil belajar yang 
selanjutnya disingkat (THB) yang digunakan untuk menganalisis kemampuan peserta didik. RPP, bahan ajar, media, LKPD, dan THB merupakan seperangkat alat pembelajaran yang digunakan oleh guru dalam kelas. Perangkat pembelajaran ini dirancang sendiri oleh guru yang disesuaikan dengan kurikulum yang berlaku. Jika rancangan proses pembelajaran tidak berjalan secara efektif maka akan mempengaruhi hasil belajar peserta didik. Masalah yang terjadi di SMAN 11 Makassar bahwa kurangnya inovasi terhadap perangkat pembelajaran yang bersifat kontekstual yang dapat meningkatkan pemahaman konsep peserta didik dengan mengaitkan materi pembelajaran dengan dunia nyata peserta didik atau berdasarkan pengalaman hidup mereka yang sering mereka temui dalam kehidupan sehari-hari dan guru tidak memanfaatkan secara maksimal fasilitas laboratorium yang disediakan oleh sekolah sehingga peserta didik kurang aktif mengikuti proses pembelajaran karena mereka hanya belajar tentang konsep tapi tidak menerapkan konsep yang telah mereka pelajari melalui sebuah praktikum.

Mempelajari ilmu kimia, peserta didik diminta tidak hanya sekedar memahami fakta, konsep atau prinsip saja, tetapi juga dituntut untuk menemukan fakta dan konsep tersebut serta terampil untuk menerapkannya. Salah satu materi yang terdapat dalam pembelajaran kimia adalah materi larutan penyangga. Materi larutan penyangga merupakan suatu materi yang masih menimbulkan kebingungan pada peserta didik terutama pada konsep komponen penyangga, prinsip kerja, dan menentukan $\mathrm{pH}$ larutan penyangga.

Salah satu pendekatan yang dapat digunakan untuk meningkatkan hasil belajar peserta didik adalah pendekatan kontekstual. Pendekatan pembelajaran kontekstual atau Contextual Teaching and Learning (CTL) merupakan konsep yang membantu guru mengaitkan antara materi yang dibelajarkannya dengan situasi dunia nyata, dan mendorong peserta didik membuat hubungan antara pengetahuan yang dimilikinya dengan penerapannya dalam kehidupan mereka sebagai anggota keluarga dan masyarakat. Sehingga proses pembelajaran tidak hanya berpengaruh pada hasil belajar yang menjadi tujuan pembelajaran, namun memberikan kebermaknaan pengetahuan dan pengalaman yang bermanfaat dalam konteks dunia nyata peserta didik. Ketika proses pembelajaran dikaitkan dengan dunia nyata mendorong keaktifan peserta didik dalam memahami konsep yang dipelajari sehingga proses pembelajaran memberikan pengetahuan yang bermakna dan bermanfaat.

Berdasarkan hasil wawancara dengan seorang guru di SMAN 11 Makassar menyatakan bahwa, (1) perangkat yang ada terutama RPP jarang dilakukan sebuah inovasi terutama menyesuaikan penggunaan model pembelajaran dengan materi yang akan diajarkan atau menyesuaikan dengan lingkungan belajar peserta didik dan mengaitkan konsep kimia yang dipelajari dengan konteks dunia nyata peserta didik, (2) rancangan pembelajaran seperti RPP yang dimiliki oleh guru tidak menjabarkan setiap indikator pembelajaran kedalam beberapa pertemuan dan masih kurang jelas pembagian waktu kegiatan pembelajarannya sehingga ketika diamati RPP yang dirancang masih susah dipahami penggunaannya, (3) dalam proses pembelajaran guru tidak mengaitkan dengan kehidupan nyata atau lingkungan peserta didik, (4) jarang menggunakan LKPD, dimana di SMAN 11 masih menggunakan bentuk latihan soal-soal yang diberikan oleh guru dan mereka jarang melakukan diskusi kelompok, (5) serta tidak melakukan praktikum di laboratorium, (6) bahan ajar yang digunakan pun masih sebatas buku paket yang dimana ketersediaannya terbatas diperpustakaan sehingga peserta didik masih kurang memahami disebabkan kurangnya buku pegangan sebagai referensinya, karena pemahaman dan antusias peserta didik dalam proses pembelajaran kurang maka mempengaruhi hasil belajar peserta didik. Untuk mengatasi hal ini seorang guru harus 
mampu merancang sebuah pembelajaran yang mampu meningkatkan aktivitas pembelajaran sehingga dapat memberi pengaruh terhadap meningkatmya hasil belajar peserta didik.

Pembelajaran discovery learning dengan pendekatan kontekstual diperlukan untuk dapat memudahkan peserta didik dalam mengembangkan pengetahuannya. Materi larutan penyangga merupakan salah satu materi yang erat kaitannya dengan kehidupaan nyata peserta didik. Contohnya penggunaan bahan pengawet dalam makanan kaleng, contoh lainnya sistem penyangga yang bekerja dalam tubuh yaitu pada sistem transportasi darah, dimana darah berperan penting dalam mengangkut $\mathrm{O}_{2}$, $\mathrm{CO}_{2}$, dan sari-sari makanan ke seluruh bagian tubuh serta berperan menjaga kestabilan suhu tubuh, sehingga pada materi larutan penyangga peserta didik akan semakin merasakan manfaat dari kegiatan pembelajaran yang mereka lakukan karena kemampuan konseptual yang diperoleh berhubungan dengan kehidupan (kontekstual) peserta didik.

Perancangan proses pembelajaran yang dipadukan dengan pendekatan kontekstual diawali dengan pengkonstruksian pengetahuan yang dimiliki peserta didik dengan materi yang akan dipelajari, dengan pemberian contoh yang dikaitkan dengan konteks dunia nyata. Dalam tahap awal ini bisa dipadukan dengan sintaks dari discovery learning yaitu pemberian stimulus. Pada tahap stimulus peserta didik diberikan suatu rangsangan berupa fenomena-fenomena yang bersifat kontekstual sehingga menimbulkan rasa ingin tahu peserta didik untuk melakukan penyelidikan lebih. Tahap selanjutnya dari pendekatan kontekstual yaitu mengembangkan pengetahuan peserta didik dengan bertanya, dalam proses bertanya ini masuk kedalam sintaks kedua dari discovery yaitu identifikasi masalah. Kemudian dilanjutkan dengan proses penemuan dan masyarakat belajar melalui kegiatan diskusi antara peserta didik dan guru maupun sesama peserta didik, dalam proses ini berkaitan dengan sintak discovery learning yaitu pada tahap pengumpulan data, pengolahan data dan pembuktian. Hasil dari proses ini dipresentasikan melalui diskusi kelas dan diakhiri dengan refleksi berdasarkan pembelajaran yang telah dilakukan, proses ini masuk kedalam tahap terakhir dari sintaks discovery yaitu generalisasi.

Berdasarkan

permasalahanpermasalahan yang telah diuraikan maka diperlukan suatu proses pembelajaran yang efektif, salah satunya dengan mengembangkan perangkat pembelajaran berbasis discovery learning dengan pendekatan kontekstual, berupa RPP, bahan ajar, media, LKPD, dan THB. Dengan dikembangkannya perangkat pembelajaran berbasis discovery learning dengan pendekatan kontekstual, diharapkan dalam kegiatan pembelajaran yang memuat materi, kegiatan penyelidikan konsep, kegiatan sains dan contoh-contoh penerapan sains dalam kehidupan sehari-hari, sehingga peserta didik dapat belajar lebih aktif terutama pada materi larutan penyangga.

Pengembangan perangkat pembelajaran kimia berbasis discovery learning yang dipadukan dengan pendekatan kontekstual dapat meningkatkan hasil belajar peserta didik diharapkan memiliki hasil yang valid, praktis, dan efektif hal ini didukung oleh penelitian (Zuriatni, Y., dkk. 2019) bahwa model guided discovery dengan pendekatan kontekstual berpengaruh terhadap peningkatan hasil belajar kognitif peserta didik pada materi laju reaksi dengan hasil gain score rata-rata sebesar 0,7 dengan kategori tinggi. (Oktavianie, M. A., dkk. 2018) bahwa pengembangan buku pengayaan kimia berbasis kontekstual pada konsep elektrokimia yang diujicobakan di kelas XII IPA 1 SMAN 18 Kabupaten Tangerang mendapatkan skor respon siswa sebesar $82,49 \%$ termasuk dalam kategori layak dengan predikat baik, selaras dengan penelitian (Ratnasari, N. D., 2018) bahwa model pembelajaran discovery learning berbasis kontekstual mampu meningkatkan kemampuan berpikir reflektif matematika 
dan penggunaan model tersebut lebih efektif dibandingkan model discovery learning biasa. Sejalan juga dengan penelitian (Anugraheni, Oetomo, \& Santosa, 2018) bahwa terdapat pengaruh model pembelajaran discovery learning dengan pendekatan kontekstual terhadap keterampilan argumentasi tertulis ditinjau dari kemampuan akademik peserta didik dalam pembelajaran biologi.

Bertolak dari latar belakang diatas, maka peneliti terdorong untuk meneliti "Pengembangan Perangkat Pembelajaran Kimia Berbasis Discovery Learning dengan Pendekatan Kontekstual Pada Materi Larutan Penyangga Kelas XI SMA/MA”. Pengembangan perangkat pembelajaran berbasis discovery learning dengan pendekatan kontekstual ini menggunakan model pengambangan 4-D, yang terbagi dalam empat tahap, yaitu pendefenisian (define), perancangan (design), pengembangan (develop), dan penyebaran (dessiminate).

\section{METODE}

Penelitian ini termasuk dalam jenis penelitian Research and Development (R\&D) yang dikembangkan dengan menggunakan model pengembangan 4-D oleh Thiagarajan (1974). Uji coba perangkat dilaksanakan di SMA Negeri 11 Makassar dengan subjek penelitian kelas XI semester genap tahun pelajaran 2019/2020.

Pengembangan perangkat pembelajaran kimia ini merujuk pada 3 syarat kualitas produk yaitu valid, praktis, dan efektif. Informasi 3 syarat kualitas tersebut digunakan instrument-instrumen penelitian. Adapun Instrumen penelitian yang digunakan adalah lembar validasi untuk melihat tingkat kevalidan produk. Lembar observasi keterlaksanaan pembelajaran, angket respon guru, dan angket respon peserta didik untuk melihat tingkat kepraktisan, dan tes hasil belajar instrumennya soal essay 6 nomor, lembar pengamatan sikap dan psikomotorik untuk melihat tingkat keefektifan. Teknik analisis data yang digunakan yakni teknik analisis statistik deskriptif. Data yang dianalisis adalah: Analisis data kevalidan perangkat pembelajaran, analisis data kepraktisan perangkat pembelajaran, dan analisis data keefektifan perangkat pembelajaran.

\section{HASIL DAN PEMBAHASAN}

\section{Proses Pengembangan Perangkat Pembelajaran Berbasis Discovery Learning}

Proses pengembangan perangkat pembelajaran berbasis discovery learning ini menggunakan model 4D dari Thiagarajan yang terdiri dari empat tahap yaitu define, design, develop, dan disseminate. Tahapan yang dilakukan dimulai dari analisis awal akhir yang bertujuan untuk mengetahui dan menetapkan masalah dasar yang dihadapi dalam proses pembelajaran. Masalah mendasar dari SMA Negeri 11 Makassar yaitu Berdasarkan hasil observasi kegiatan pembelajaran kimia di SMAN 11 Makassar diketahui bahwa dalam proses pembelajaran yang dilakukan oleh guru pada tahap pendahuluan kurang mengaitkan pembelajaran kimia dengan kehidupan sehari-hari peserta didik atau bersifat kontekstual, pemberian apersepsi yang dilakukan lebih bersifat konseptual sehingga banyak peserta didik yang kurang antusias mengikuti pembelajaran dan mereka mengalami kesulitan dalam pembelajaran kimia, analisis peserta didik untuk mengetahui karakteristik peserta didik yang sesuai dengan rancangan dan pengembangan perangkat pembelajaran melalui observasi, hasil yang diperoleh bahwa peserta didik di SMA Negeri 11 Makassar memiliki kemampuan heterogen yakni berkemampuan tinggi, sedang, dan rendah. Peserta didik pada umumnya memiliki gaya belajar visual yakni belajar dengan mengutamakan indera pengelihatan dimana peserta didik lebih tertarik jika divisualisasikan baik melalui gambar maupun dialami secara langsung seperti praktikum, dan diperlihatkan dengan hal-hal yang berkaitan dengan kehidupan sehari-hari, analisis materi, pada analisis ini diperoleh konsep-konsep utama dalam materi larutan penyangga dan dibuat dalam 
suatu urutan materi hirarkis, analisis tugas, setelah dilakukan analisis ini diperoleh bahwa tugas yang diberikan dapat memberikan pemahaman terhadap materi yang sedang dipelajari, analisis tujuan pembelajaran, tahap ini terdiri atas 3 langkah yaitu (1) penyusunan tes, (2) pemilihan media yang sesuai tujuan, (3) pemilihan format, menentukan format isi perangkat pembelajaran. Untuk itu dipilih format yang sesuai dengan karakteristik dan langkah-langkah pembelajaran discovery learning tahapan selanjutnya adalah mengembangkan perangkat pembelajaran meliputi RPP, LKPD, BAPD, Media, dan THB.

\section{Kualitas Perangkat Pembelajaran} Berbasis Discovery Learning

a. Kevalidan

1) Hasil Validasi terhadap Perangkat Pembelajaran

Secara umum, hasil penelitian terhadap perangkat pembelajaran yang meliputi RPP, LKPD, BAPD, Media, dan THB dapat dilihat pada Tabel 1.

Tabel 1. Rangkuman Hasil Validasi Perangkat

\begin{tabular}{clcc}
\hline No & \multicolumn{1}{c}{ Perangkat } & $\begin{array}{c}\text { Rata-rata Skor } \\
\text { Validasi }\end{array}$ & Kategori \\
\hline 1 & Rencana Pelaksanaan Pembelajaran (RPP) & 3,55 & Sangat Valid \\
2 & Lembar Kerja Peserta Didik (LKPD) & 3,65 & Sangat Valid \\
3 & Bahan Ajar Peserta Didik (BAPD) & 3,60 & Sangat Valid \\
4 & Media & 3,50 & Sangat Valid \\
5 & Tes Hasil Belajar (THB) & 3,60 & Sangat Valid \\
\hline \multicolumn{2}{c}{ Rata-rata Total } & 3,58 & Sangat Valid \\
\hline
\end{tabular}

Hasil analisis terhadap RPP pada tabel memperlihatkan bahwa rata-rata penilaian validator terhadap RPP dari aspek format RPP, materi (isi) yang disajikan, bahasa, alokasi waktu, manfaat/kegunaan RPP, sarana dan alat bantu pembelajaran adalah 3,55 dengan kategori sangat valid karena berada pada rentang $3,5 \leq \mathrm{X} / \mathrm{Y} / \mathrm{Z} \leq 4$. Hal ini berarti bahwa RPP disusun sesuai dengan prinsip-prinsip pengembangan RPP dan seluruh komponen dalam penyusunan RPP telah tercantum sehingga RPP ini dapat diterapkan dalam kegiatan pembelajaran. Meskipun demikian ada beberapa aspek yang perlu diperhatikan agar dapat menghasilkan RPP yang lebih baik yakni ketepatan penjabaran kompetensi dasar ke indicator pencapaian kompetensi, pengembangan indikator menjadi tujuan pembelajaran, dan kesesuaian tujuan pembelajaran dengan tingkat perkembangan kognitif peserta didik. Hasil uji kelayakan terhadap perangkat pembelajaran juga dilakukan oleh Siwi Khomsiatun, dkk (2015), hasil validasi RPP menunjukkan total skor adalah 495 sehingga RPP termasuk dalam kategori "valid" sehingga RPP yang dihasilkan layak digunakan setelah dilakukan perbaikan-perbaikan sesuai aturan.

Hasil analisis terhadap LKPD memperlihatkan bahwa rata-rata penilaian terhadap LKPD ditinjau dari aspek format LKPD, bahasa, isi LKPD, waktu, manfaat/kegunaan LKPD adalah 3,65 dengan kategori "sangat valid" yaitu berada pada rentang 3,5 $\leq \mathrm{X} / \mathrm{Y} / \mathrm{Z} \leq 4$. Hal ini berarti bahwa LKPD ini dapat digunakan sebagai bahan ajar dalam kegiatan pembelajaran. Namun demikian berdasarkan saran dan komentar validator maka dilakukan revisi kecil untuk penyempurnaan perangkat LKPD. (1) cantumkan indikator pembelajaran pada setiap LKPD, (2) cantumkan keterangan gambar pada setiap gambar yang ditampilkan, (3) Tampilkan sisi kontekstual pada perancangan LKPD. Hasil uji kelayakan LKPD juga dilakukan oleh Dyah Putri Hutami dan Yusman Wiyatmo 
(2018), berdasarkan penilaian validator LKPD yang dihasilkan termasuk dalam kategori sangat baik dengan skor rata-rata sebesar 4,4.

Hasil analisis terhadap BAPD memperlihatkan bahwa rata-rata penilaian terhadap bahan ajar peserta didik ditinjau dari aspek adalah format BAPD, bahasa, isi BAPD, dan manfaat/kegunaan BAPD adalah 3,6 dengan kategori "sangat valid" yaitu berada pada rentang 3,5 $\leq \mathrm{X} / \mathrm{Y} / \mathrm{Z} \leq 4$. Hal ini berarti bahwa BAPD telah dapat digunakan sebagai bahan ajar dalam kegiatan pembelajaran. Namun demikian berdasarkan saran dan komentar validator maka dilakukan revisi kecil untuk penyempurnaan perangkat bahan ajar peserta didik. (1) sebaiknya dicantumkan indikator pembelajaran pada setiap BAPD yang dikembangkan, (2) sebaiknya dicantumkan setiap keterangan gambar jika terdapat lebih dari satu gambar pada satu kesatuan gambar yang ditampilkan (3) Konsep larutan penyangga yang ditampilkan harus lebih kontekstual (4) gambar yang ditampilkan lebih menarik. Hasil penelitian ini sejalan dengan hasil penelitian yang dilakukan oleh Yusnita, dkk (2014), diperoleh hasil validasi buku peserta didik yaitu semua komponen penilaian berada dalam kategori "sangat baik" sehingga perangkat layak digunakan.

Hasil analisis terhadap THB memperlihatkan bahwa rata-rata penilaian terhadap THB ditinjau dari aspek materi soal, konstruksi, dan bahasa adalah 3,6 dengan kategori "sangat valid" yaitu berada pada rentang $3,5 \leq \mathrm{X} / \mathrm{Y} / \mathrm{Z} \leq 4$. Namun demikian, tes hasil belajar yang disusun tetap direvisi sedikit dengan memperhatikan indikator pencapaian kompetensi,dimana soal yang dibuat harus sesuai dan mengurangi jumlah soal sesuai waktu dan level kognitif peserta didik. Tes hasil belajar yang telah direvisi diujicobakan sebelum pembelajaran kimia berbasis discovery learning dengan pendekatan kontekstual pada materi larutan penyangga untuk mengetahui kemampuan awal peserta didik dan setelah proses pembelajaran berbasis discovery learning dengan pendekatan kontekstual untuk mengukur hasil belajar peserta didik setelah mengikuti proses pembelajaran.

2) Hasil Validasi terhadap Instrumen Penelitian

Dalam proses pengembangan instrumen ini terdapat beberapa instrumen pengumpulan data yang dikembangkan melalui proses validasi. Instrumen yang dimaksud adalah lembar keterlaksanaan pembelajaran, lembar angket respon guru, lembar angket respon peserta didik, dan lembar kemampuan pemecahan masalah. Adapun rekapitulasi penilaian validator terhadap instrumen penelitian dapat dilihat pada Tabel 2.

Tabel 2. Rekapitulasi Hasil Validasi terhadap Instrumen Penelitian

\begin{tabular}{clcc}
\hline No & \multicolumn{1}{c}{ Perangkat pembelajaran } & Penilaian & Kategori \\
\hline 1 & Lembar observasi keterlaksanaan & 3,9 & Sangat Valid \\
& pembelajaran & & \\
2 & Lembar angket respon guru & 3,8 & Sangat Valid \\
3 & Lembar angket respon peserta didik & 3,8 & Sangat Valid \\
\hline & $\quad$ Rata-rata Total & 3,83 & Sangat Valid \\
\hline
\end{tabular}

Berdasarkan Tabel 2, menunjukkan bahwa keseluruhan komponen lembar keterlaksanaan pembelajaran, lembar angket respon guru, lembar angket respon peserta didik, dinilai sangat valid yaitu berada pada rentang $3,7 \leq \mathrm{X} / \mathrm{Y} / \mathrm{Z} \leq 4$. Penilaian secara umum oleh para ahli untuk instrumen penelitian ini adalah baik dan dapat digunakan dengan sedikit revisi.

b. Kepraktisan

1) Keterlaksanaan Perangkat Pembelajaran Tujuan utama analisis data keterlaksanaan perangkat pembelajaran adalah untuk melihat sejauh mana 
tingkat keterlaksanaan perangkat dalam proses pembelajaran. Berdasarkan hasil analisis data dan observasi pengamatan tentang keterlaksanaan pembelajaran selama empat pertemuan dirangkum pada Tabel 3.

Tabel 3. Hasil Analisis Pengamatan Keterlaksanaan Perangkat Pembelajaran

\begin{tabular}{clcc}
\hline No & \multicolumn{1}{c}{ Aspek } & Penilaian & Kategori \\
\hline 1 & Sintaks & 1,72 & Terlaksana Seluruhnya \\
2 & Interaksi Sosial & 1,78 & Terlaksana Seluruhnya \\
3 & Prinsip Reaksi & 1,7 & Terlaksana Seluruhnya \\
4 & Sistem Pendukung & 1,78 & Terlaksana Seluruhnya \\
\hline & Rata-rata Total & 1,74 & Terlaksana Seluruhnya \\
\hline
\end{tabular}

Berdasarkan analisis data yang ditunjukkan pada Tabel 3, nilai rata-rata keterlaksanaan perangkat pembelajaran kimia berbasis discovery learning adalah 1,74 dengan kategori terlaksana seluruhnya karena berada pada rentang $1,5 \leq \mathrm{M} \leq 2,0$. Hal ini menunjukkan bahwa perangkat pembelajaran yang dikembangkan dapat digunakan dalam pembelajaran kimia di kelas khususnya untuk materi larutan penyangga. Berdasarkan hasil penilaian pengamat dan hasil analisis persentase kesepahaman dapat disimpulkan bahwa keterlaksanaan perangkat pembelajaran kimia telah diujicobakan dan telah memenuhi kirteria praktis.

2) Respon Guru

Tujuan utama analisis data respon guru terhadap proses pembelajaran adalah untuk melihat bagaimana respon guru terhadap perangkat pembelajaran berbasis discovery learning dengan pendekatan kontekstual. Hasil analisis tersebut dapat dilihat pada Tabel 4.

Tabel 4. Hasil Analisis Respon Guru

\begin{tabular}{clcl}
\hline No & \multicolumn{1}{c}{ Aspek } & Penilaian & Kategori \\
\hline 1 & Penilaian terhadap RPP & 90,00 & Sangat Positif \\
2 & Peniilaian terhadap LKPD & 92,50 & Sangat Positif \\
3 & Penilaian terhadap BAPD & 95,83 & Sangat Positif \\
4 & Penilaian terhadap Media & 88,64 & Sangat Positif \\
5 & Penilaian terhadap THB & 91,07 & Sangat Positif \\
\hline & Rata-rata Total & 91,61 & Sangat Positif
\end{tabular}

Berdasarkan hasil yang ditunjukkan pada Tabel 4, rata-rata respon guru sebesar 91,61 yaitu berada pada kategori sangat positif. Hal ini berarti bahwa perangkat pembelajaran yang telah dikembangkan praktis dan dapat digunakan dalam pembelajaran kimia berbasis discovery learning dengan pendekatan kontekstual.

Hasil analisis respon guru terhadap RPP menunjukkan bahwa hal yang perlu diperhatikan yaitu kesesuaian antara banyaknya indikator dengan waktu yang disediakan, rincian waktu yang digunakan dalam RPP cukup untuk setiap pertemuan. Respon guru terhadap BAPD yang perlu diperhatikan yaitu materi yang ada dalam buku peserta didik lengkap, menarik tetapi masih ada beberapa bagian yang belum dipahami, gambar yang disajikan dalam buku peserta didik belum sepenuhnya membantu dalam memahami materi yang dipelajari. masih diperlukan penjelasan konsep yang lebih lengkap. Hasil analisis respon guru terhadap LKPD, yang perlu diperhatikan yaitu waktu yang dibutuhkan dalam setiap kegiatan pada LKPD terutama pada saat pengolahan data, serta kemudahan penggunaan LKPD berbasis discovery learning dengan pendekatan kontekstual, terutama dalam mengubah 
kebiasaan peserta didik dalam belajar di kelas.

3) Respon Peserta Didik

Angket respon peserta didik diberikan setelah mengikuti kegiatan pembelajaran, respon peserta didik terhadap perangkat pembelajaran dibagi menjadi tiga aspek yaitu respon terhadap perangkat pembelajaran dan proses pembelajaran, respon terhadap bahan ajar peserta didik, dan respon terhadap lembar kerja peserta didik. Hasil analisis data respon peserta didik diisi oleh 27 peserta didik dan dapat dilihat pada Tabel 5 .

Tabel 5. Hasil Analisis Respon Peserta Didik

\begin{tabular}{clcc}
\hline No & \multicolumn{1}{c}{ Aspek } & Rata-rata Persentase & Keterangan \\
\hline 1 & Respon terhadap perangkat & 85,06 & Sangat Positif \\
& pembelajaran dan proses pembelajaran & & \\
2 & Respon terhadap BAPD & 88,58 & Sangat Positif \\
3 & Respon terhadap LKPD & 88,43 & Sangat Positif \\
\hline \multicolumn{2}{r}{ Rata-rata Total } & 87,36 & Sangat Positif \\
\hline
\end{tabular}

Respon peserta didik terhadap pelaksanaan pembelajaran berdasarkan angket yang diberikan diperoleh persentase sebesar 85,06\%, respon peserta didik terhadap bahan ajar peserta didik sebesar $88,58 \%$ dan respon terhadap LKPD sebesar 88,43\%. Dari keseluruhan aspek yang diamati rata-rata respon positif yang diberikan oleh peserta didik adalah $87,36 \%$. Hal ini menunujukkan bahwa ratarata peserta didik setuju terhadap pelaksanaan pembelajaran berbasis discovery learning, dan seluruh aspek yang ditanyakan dalam pelaksanaan kegiatan pembelajaran dengan menggunakan perangkat pembelajaran kimia berbasis discovery learning didapatkan respon positif yang sangat tinggi atau sangat positif. Dari persentase tersebut menunjukan bahwa kriteria perangkat pembelajaran dikatakan praktis jika respon peserta didik minimal berada pada kategori positif, sehingga perangkat pembelajaran praktis digunakan dalam kegiatan pembelajaran.

Dari analisis respon peserta didik, rata-rata peserta didik memberikan penilaian dalam skala setuju, respon peserta didik positif terhadap kegiatan pembelajaran, LKPD, BAPD berbasis discovery learning dengan pendekatan kontekstual. Dengan pembelajaran berbasis discovery learning minat belajar peserta didik lebih baik, terlibat aktif dalam belajar kelompok untuk memperoleh pengetahuan, berdiskusi, bertukar ide. Saran untuk LKPD yaitu perlu penambahan ruang kosong untuk menuliskan jawaban, peserta didik menganggap ruang yang disediakan tidak cukup untuk menuliskan beberapa jawaban. Untuk BAPD diharapkan untuk didesain lebih menarik sehingga peserta didik lebih termotivasi untuk belajar masih dierlukan tambahan contoh soal sehingga bisa menjadi referensi bagi peserta didik dalam menyelesaikan soal-soal yang terkait.

c. Keefektifan

Pengkategorian hasil belajar berdasarkan kategori diperoleh distribusi frekuensi, persentase, dan ketuntasan hasil belajar nilai hasil belajar dapat dilihat pada Tabel 6 dan Tabel 7.

Tabel 6. Distribusi Frekuensi dan Persentase Nilai Hasil Belajar Kimia

\begin{tabular}{ccccc}
\hline $\begin{array}{c}\text { Interval } \\
\text { Nilai }\end{array}$ & Predikat & Keterangan & \multicolumn{2}{c}{ Post-test } \\
\hline & & & Frekuensi & Persentase \\
\cline { 4 - 5 } $93-100$ & $\mathrm{~A}$ & Sangat Baik & 1 & 3,71 \\
$85-92$ & $\mathrm{~B}$ & Baik & 5 & 18,52 \\
$75-84$ & $\mathrm{C}$ & Cukup & 17 & 62,96 \\
\hline
\end{tabular}




\begin{tabular}{lllll}
\hline$<75$ & D & Kurang & 4 & 14,81 \\
\hline
\end{tabular}

Tabel 7. Deskripsi Ketuntasan Hasil Belajar

\begin{tabular}{ccccc}
\hline \multirow{2}{*}{ Interval Nilai } & \multirow{2}{*}{ Predikat } & \multirow{2}{*}{ Keterangan } & \multicolumn{2}{c}{ Post-test } \\
\cline { 4 - 5 } & & & Frekuensi & Persentase \\
\hline $75-100$ & Tuntas & Sangat baik & $\mathbf{2 3}$ & $\mathbf{8 5 , 1 9}$ \\
$0-74$ & Tidak tuntas & Baik & $\mathbf{4}$ & $\mathbf{1 4 , 8 1}$ \\
\hline
\end{tabular}

Berdasarkan hasil analisis pada Tabel 6, menunjukkan bahwa dari 27 peserta didik yang mengikuti tes hasil belajar setelah dilakukan proses pembelajaran menggunakan perangkat pembelajaran berbasis discovery learning dengan pendekatan kontekstual terdapat $14,81 \%$ pada kategori kurang $62,96 \%$ pada kategori cukup, $18,52 \%$ pada kategori baik, dan $3,71 \%$ pada kategori sangat baik. Tabel 7 , menunjukkan bahwa dari 27 peserta didik setelah dilakukan proses pembelajaran menggunakan perangkat pembelajaran berbasis discovery learning dengan pendekatan kontekstual terdapat $85,19 \%$ peserta didik yang tuntas dan $14,81 \%$ peserta didik yang tidak tuntas. Pembelajaran dikatakan berhasil secara klasikal jika minimal $80 \%$ peserta didik mencapai nilai minimal yaitu 75 . Berdasarkan persentase penguasaan tes hasil belajar peserta didik memenuhi standar ketuntasan secara klasikal.

Pada dasarnya penelitian seperti ini telah pernah dilakukan oleh peneliti sebelumnya Izzah Fatimah Azzahrah (2014). Dari hasil penelitian diperoleh data menunjukkan bahwa secara klasikal, peserta didik memperoleh pemahaman yang baik terhadap materi yang disajikan dengan menggunakan perangkat pembelajaran kimia berbasis discovery learning. Penelitian yang dilakukan oleh Nurwahidah dengan demikian, perangkat pembelajaran kimia berbasis discovery learning efektif digunakan pada pembelajaran larutan penyangga.

\section{SIMPULAN DAN SARAN}

Berdasarkan hasil penelitian, maka kesimpulan dari penelitian ini adalah pengembangan perangkat pembelajaran pada penelitian ini menggunakan model 4-D yang terdiri dari 4 tahap, yaitu pendefenisian (define), perancangan (design), pengembangan (develop), dan tahap penyebaran (dessiminate). Secara umum hasil pengembangan perangkat pembelajaran dalam penelitian ini valid, praktis, dan efektif. (a) Valid, berdasarkan hasil validasi oleh ahli pada perangkat pembelajaran berupa Rencana Pelaksanaan Pembelajaran (RPP), Lembar Kegiatan Peserta Didik (LKPD), Bahan Ajar Peserta Didik (BAPD), media dan tes Hasil Belajar (THB) dikategorikan "Sangat Valid", (b) praktis, berdasarkan hasil pengamatan oleh observer bahwa perangkat pembelajaran terlaksana Seluruhnya" pada saat uji coba, sedangkan secara keseluruhan respon guru dan peserta didik berada pada kategori "Sangat Positif" dan (c), efektif, dimana ketuntasan belajar peserta didik secara klasikal tercapai.

Berdasarkan hasil penelitian, maka dikemukakan saran-saran sebagai berikut, pengembangan perangkat pembelajaran kimia berbasis discovery learning hendaknya dikembangkan untuk materi lain yang cocok diajarkan dengan model ini, sehingga peserta didik akan lebih termotivasi dan dapat mengkonstruksi sendiri pengetahuannya dan bagi peneliti yang berminat mengembangkan lebih lanjut penelitian ini, diharapkan untuk melihat bagaimana kondisi peserta didik dan menggunakan observer yang disesuaikan dengan banyaknya komponen yang diamati.

\section{DAFTAR RUJUKAN}

Anugraheni, Dhimar, A., Oetomo, D., \& Santosa, S. (2018). Pengaruh Model Discovery Learning dengan 
pendekatan Contextual Teaching Learning terhadap Keterampilan Argumentasi Tertulis Ditinjau dari Kemampuan Akademik Siswa SMAN Karangpandan. Jurnal Pendidikan Biologi. 11(2).

Aqib, Z. (2018). Model-Model, Media, dan Strategi Pembelajaran Kontekstual (Inovatif). Bandung: Yrama Widya.

Azzahroh, Fatimah, I., Raharjo, \& Sudibyo, E. (2014). Pengembangan Perangkat Pembelajaran Berbasis Discovery Learning Pada Sub Materi Respirasi dan fotosintesis Kelas VII SMP. Jurnal mahasiswa UNESA.

Dyah, P. H., \& Yusman, W. (2018). Pengembangan Perangkat Pembelajaran Berbasis Guided Discovery Learning untuk Meningkatkan Pemahaman Konsep dan Kemampuan Kerjasama Peserta Didik. Jurnal Pendidikan Fisika, 7(1).

Masrura, L. (2017). Penggunaan LKS Berbasis Discovery Learning Pada Materi Asam Basa Terhadap Hasil Belajar Siswa Di MAS Oemar Diyan Aceh Besar. Skripsi. Fakultas Tarbiyah dan Keguruan (FTK) Universitas Islam Negeri Ar-raniry Darussalam.

Nieveen, N. (1999). Prototyping to Reach Product Quality. Dalam Plomp, T; Nieveen, N; Gustafson, K; Branch, R.M; dan van den Akker, J (eds). Design Approaches and Tools in Education and Training. London: Kluwer Academic Publisher.

Nurwahidah, Danial, M., \& Mansyur. (2018). Pengembangan Perangkat Pembelajaran Kimia Berbasis Discovery Learning Pada Materi Larutan Penyangga Di Kelas XI SMA. CER. Universitas Negeri Makassar.

Oktavianie, M. A., Dedi I., \& Dewi M. (2018). Pengembangan Buku Pengayaan Kimia Berbasis Kontekstual pada Konsep
Elektrokimia. Jurnal Tadris Kimiya. ISSN 2527-6816.

Ratnasari, Indah, P. (2018). Pengembangan Model Discovery Learning Berbasis Kontekstual untuk Meningkatkan kemampuan Berpikir Reflektif Matematis dan Efficacy siswa. Tesis. Universitas Lampung.

Siwi, K., \& Retnawati, H. (2015). Pengembangan Perangkat Pembelajaran dengan Penemuan Terbimbing (Discovery Learning) untuk Meningkatkan Kemampuan Pemecahan Masalah. Jurnal Riset Matematika. 2(1), 92-106.

Thiagarajan, Sivasailam, dkk. (1974). Instructional Development for Training Teachers of Exceptional Children. Washinton DC: National Center for Improvement Educational System.

Yusnita, R., dkk. (2014). Pengembangan Perangkat Pembelajaran Berbasis Penemuan Terbimbing (Guided Discovery) Dengan Pendekatan Somatic, Auditory, Visual, Intellectual (SAVI) Pada Materi Pokok Peluang Kelas IX SMP Tahun Ajaran 2013/2014. Jurnal Elektronik Pembelajaran Matematika. 2(4).

Zuriatni, Y., Endang B., \& Sumari. (2019). Pengaruh Model Pembelajaran Guided Discovery Learning dengan Pendekatan Kontekstual terhadap Hasil Belajar Kognitif. Jurnal Pendidikan, 4(6). 